\title{
EFEITO DO PROCESSAMENTO, SUPLEMENTAÇÃO ENZIMÁTICA E NÍVEL NUTRICIONAL DA RAÇ̃̃O PARA FRANGOS DE CORTE NO PERÍODO DE 22 A 42 DIAS DE IDADE ${ }^{1}$
}

\author{
Effect of processing, enzymatic supplementation and nutritional levels of \\ the diet for broilers in the period from the $22^{\text {nd }}$ to the $42^{\text {nd }}$ day of age ${ }^{1}$ \\ Luiz Eduardo Avelar Pucci², Paulo Borges Rodrigues 3 , Rilke Tadeu Fonseca de Freitas ${ }^{3}$, \\ Elias Tadeu Fialho ${ }^{3}$, Germano Augusto Jerônimo do Nascimento ${ }^{4}$, Renata Ribeiro Alvarenga ${ }^{3}$
}

\begin{abstract}
RESUMO
Objetivando-se avaliar a forma física da ração, o uso de enzimas e níveis nutricionais em dietas à base de milho e farelo de soja, foram conduzidos dois experimentos utilizando um total de 1.344 frangos de corte machos de 22 a 42 dias de idade, distribuídos em um delineamento inteiramente casualizado em esquema fatorial 2 × 2 × 2, sendo duas formas físicas de ração (farelada ou triturada); com ou sem complexo enzimático (amilase, celulase e protease) e dois níveis nutricionais, 95 ou 100\% das recomendações de Rostagno et al. (2005). No experimento 1, 1200 aves foram distribuídas nos oito tratamentos com cinco repetições de 30 aves cada para avaliação de consumo de ração (CR), ganho de peso (GP), conversão alimentar (CA) e características de carcaça. Simultaneamente, foi realizado o experimento 2 (ensaio de metabolismo), em que 144 aves foram distribuídas em gaiolas metálicas, recebendo os oito tratamentos experimentais com seis repetições de três aves cada. Aos 38 dias de idade iniciou-se a coleta total de excretas, realizada uma vez ao dia, por três dias consecutivos para determinação da energia metabolizável aparente corrigida (EMAn) e dos coeficientes de metabolizabilidade da matéria seca (CMMS) e proteína bruta (CMPB) das rações experimentais. De uma maneira geral, pelos resultados obtidos, pode-se concluir que a suplementação enzimática não resulta em melhora no desempenho das aves e na digestibilidade dos nutrientes das rações, independentemente da forma física, devendo estas serem formuladas com 100\% das recomendações nutricionais.
\end{abstract}

Termos para indexação: Complexo enzimático, desempenho, digestibilidade, peletização.

\section{ABSTRACT}

In order to evaluate the physical form of diet and the use of enzymes and nutritional levels in diets based on corn and soybean meal, two experiments were carried out using a total of 1344 male broilers from 22 to 42 days of age, distributed in a randomized design in a $2 \times 2 \times 2$ factorial scheme with two physical forms of diet (meal or crushed), with and without enzymatic complex (amylase, cellulase and protease) and two nutritional levels (95 or 100\% of the recommendations). In experiment 1, 1200 birds were distributed to the eight treatments with five replicates of 30 chickens each, to evaluate the feed intake (FI), weight gain (WG) and feed conversion (FC) and carcass traits of birds. Simultaneously, in the experiment 2 (assay metabolism), 144 birds were distributed in metal cages and received the eight experimental treatments in six replicates of three birds each. At 38 days of age the total excreta collection were started, and the collect for three consecutive days to determine the apparent metabolizable energy corrected (AMEn) and the metabolizability coefficients of dry matter (MCDM) and crude protein (MCCP) of experimental diets. In general, the results can conclude that enzyme supplementation results in no improvement in bird performance and nutrient digestibility of diets, regardless of physical form, which should be made with $100 \%$ nutritional recommendations.

Index terms: Digestibility, enzimatic complex, pelleting, performance.

(Recebido em 30 de março de 2010 e aprovado em 14 de agosto de 2010)

\section{INTRODUÇÃO}

A produção animal tem como princípios transformar alimentos de baixo valor nutricional e menos palatáveis em alimentos de alto valor nutritivo. Nessa área, a avicultura pode ser considerada uma das atividades que mais têm evoluído, possibilitando à indústria avícola uma enorme capacidade para prover os consumidores de fontes protéicas saudáveis a baixo custo. Este êxito na produção avícola é resultado da integração e dos avanços nas áreas de melhoramento genético, nutrição, sanidade e manejo.

Na nutrição, estratégias como o processamento das rações e a utilização de aditivos alimentares são alternativas com a finalidade de melhorar e garantir o fornecimento e o aproveitamento adequado dos nutrientes contidos nas rações, visando melhorar o desempenho das aves. Entre os aditivos, Zanella et al. (1999) relataram o desafio de se

\footnotetext{
${ }^{1}$ Parte da tese do primeiro autor

2Universidade Federal de Lavras/UFLA - Departamento de Zootecnia/DZO - Cx. P. 3037 - 3200-000 - Lavras, MG - lepucci74@yahoo.com.br

${ }^{3}$ Universidade Federal de Lavras/UFLA - Departamento de Zootecnia/DZO - Lavras, MG
}

${ }^{4}$ Universidade federal do Ceará/UFC - Departamento de Zootecnia/DZO - Fortaleza, CE 
desenvolverem enzimas para dietas de baixa viscosidade, constituídas por milho, sorgo e farelo de soja, que representam as principais matérias-primas utilizadas em dietas avícolas no Brasil. Para Souza et al. (2008), a utilização de várias enzimas em dietas à base de milho e farelo de soja, para aves, já é uma realidade e tem como objetivo de complementar as enzimas endógenas produzidas, aumentando a digestibilidade dos demais nutrientes, e como consequência, melhorando o desempenho. Pucci et al. (2003) citam que as enzimas exógenas adicionadas às rações visam remover ou hidrolisar fatores antinutricionais como os polissacarídeos não amiláceos (PNA's). Minimizar a excreção de nutrientes não digestíveis no meio ambiente, diminuindo o impacto ambiental da cadeia produtiva, também é uma grande vantagem atribuída ao uso de enzimas na nutrição avícola.

A peletização e posterior trituração estão entre os tipos de processamentos de rações mais utilizados pela avicultura, devido ao fato das mesmas proporcionarem facilidade de manejo e melhorarem a eficiência alimentar das aves. Logato et al (2009) destacam que processos térmicos, como peletização e extrusão, modificam a estrutura de carboidratos melhorando sua utilização pelos animais. Porém, as condições de processamento das rações, como a peletização, podem afetar a termoestabilidade de aditivos empregados devido às temperaturas utilizadas no processo, prejudicando assim, seu efeito esperado (Souza et al., 2008).

Desta forma, o objetivo deste trabalho foi avaliar o efeito do processamento de rações com diferentes níveis nutricionais e suplementação enzimática sobre o desempenho, características de carcaça e digestibilidade de nutrientes de frangos de corte de 22 a 42 dias de idade.

\section{MATERIAL E MÉTODOS}

Dois experimentos foram realizados no Setor de Avicultura do Departamento de Zootecnia da Universidade Federal de Lavras - DZO/UFLA - na cidade de Lavras, Minas Gerais, no período de 22/12/2007 a 11/01/2008 em que foram utilizados um total de 1344 pintos de corte, machos, da linhagem Cobb 500, sendo 1200 no ensaio de desempenho e 144 no ensaio de metabolismo. As aves foram criadas até 21 dias de idade com rações pré-inicial e inicial, com milho e farelo de soja como ingredientes básicos, formuladas de acordo com as exigências nutricionais recomendadas por Rostagno et al. (2005), sendo então pesadas e distribuídas aleatoriamente em um galpão de alvenaria com 60 boxes de $3,0 \mathrm{~m}^{2}$ cada, com piso de cimento coberto por maravalha de madeira. Cada boxe conteve um comedouro tubular, um bebedouro pendular $\mathrm{e}$ uma lâmpada incandescente de $150 \mathrm{~W}$ como fonte de aquecimento. Durante esse período as aves receberam água e ração à vontade.

As rações experimentais foram formuladas à base de milho e farelo de soja, com diferentes formas físicas (ração farelada - RF ou ração triturada - RT, peletizada e posteriormente moída), com a adição ou não de enzimas (sem enzimas - SE e com enzimas - CE, complexo enzimático Allzyme Vegpro $^{\circledR}$ - 0,5 kg/t, contendo amilase, celulase e protease) e com dois níveis nutricionais, 95 e $100 \%$ das exigências recomendadas por Rostagno et al. (2005). A composição percentual e calculada das rações está apresentada na Tabela 1.

As rações experimentais (fareladas e peletizadas) foram preparadas e processadas na indústria de rações Total Alimentos S.A., na cidade de Três Corações, MG. Após esse processo, as rações peletizadas foram trituradas (triturador tipo martelo) na fábrica de rações do DZO/ UFLA, buscando-se manter uma granulometria semelhante à das rações fareladas, cujo diâmetro geométrico médio (DGM) foi determinado segundo a metodologia descrita por Zanotto \& Bellaver (1996).

No experimento 1 (ensaio de desempenho), os frangos de corte de 22 dias de idade, com peso médio inicial de 695,6 \pm 7,1 g, foram distribuídos segundo um delineamento inteiramente casualizado em esquema fatorial $2 \times 2 \times 2$, em cinco repetições de 30 aves cada, com duas formas físicas de rações (farelada e triturada), sem ou com adição de complexo enzimático (amilase, celulase e protease) e com dois níveis nutricionais (95 e 100\%).

Aos 42 dias de idade foram realizadas pesagens para serem avaliados consumo de ração - $\mathrm{CR}$, ganho de peso - GP e conversão alimentar - CA. Após a pesagem final, duas aves de cada unidade experimental, com peso próximo à média da parcela, foram retiradas para avaliação das características de carcaça (rendimento de carcaça $\mathrm{RC}$, rendimento de peito $-\mathrm{RP}$, rendimento de coxa + sobre coxa $-\mathrm{RC}+\mathrm{SC}$ e porcentagem de gordura abdominal - GA), sendo submetidas a um jejum de 12 horas e, após esse período, pesadas e abatidas. Após o abate, realizado por sangria na artéria jugular, as aves foram depenadas e evisceradas e as carcaças, sem cabeça e pés, pesadas. Para a determinação do RC, considerou-se o peso da carcaça limpa e eviscerada (sem cabeça e pés) em relação ao peso vivo após o jejum, obtido antes do abate. O RP e o RC + SC foram calculados em relação ao peso da carcaça eviscerada, e a GA através da pesagem da gordura presente na região abdominal, próxima à Bursa de Fabricius e à cloaca da ave. Simultaneamente ao ensaio de desempenho, realizou-se o ensaio de metabolismo (experimento 2 ) com objetivo de 
avaliar o valor energético das rações experimentais e a metabolizabilidade dos nutrientes. Foram adotados os mesmos procedimentos de manejo do período pré-inicial e inicial de um a 21 dias de idade, citados no experimento 1 . Aos 21 dias de idade, 144 aves com peso médio de 695,6 \pm $7,1 \mathrm{~g}$ foram transferidas para uma sala de ensaios de metabolismo, sendo alojadas e distribuídas de forma aleatória em baterias de gaiolas metálicas. Cada gaiola possuía $50 \mathrm{~cm}$ de largura x $50 \mathrm{~cm}$ de profundidade x $50 \mathrm{~cm}$ de altura, continha um comedouro do tipo calha, um bebedouro do tipo pressão e uma bandeja revestida com plástico resistente. A temperatura da sala, que oscilou de 23,8 a $27,1^{\circ} \mathrm{C}$ durante o período experimental, foi parcialmente controlada com ventiladores e exaustores automáticos e a iluminação foi constante durante todo o período experimental com 24 horas de luz artificial. Utilizou-se o mesmo delineamento experimental do ensaio de desempenho, no qual as oito rações experimentais foram fornecidas a seis repetições de três aves cada até os 38 dias de idade. Após esse período, iniciou-se a coleta total de excretas que foi realizada uma vez ao dia, pela manhã, por um período de três dias consecutivos, conforme indicado por Rodrigues et al. (2005) e quantificados os consumos de cada parcela. As excretas foram acondicionadas em sacos plásticos, identificados e armazenados em freezer

Tabela 1 - Composição percentual e calculada das rações experimentais utilizadas para frangos de corte de 22 a 42 dias de idade.

\begin{tabular}{|c|c|c|c|c|}
\hline \multirow{3}{*}{ Ingredientes (\%) } & \multicolumn{4}{|c|}{ Nível nutricional (\%) ${ }^{1}$} \\
\hline & \multicolumn{2}{|c|}{95} & \multicolumn{2}{|c|}{100} \\
\hline & Sem enzimas & Com enzimas & Sem enzimas & Com enzimas \\
\hline Milho & 66,50 & 66,50 & 65,00 & 65,00 \\
\hline Farelo de soja & 26,20 & 26,20 & 28,60 & 28,60 \\
\hline Óleo de soja & 1,00 & 1,00 & 2,70 & 2,70 \\
\hline Fosfato bicálcico & 1,60 & 1,60 & 1,60 & 1,60 \\
\hline Calcário & 0,79 & 0,79 & 0,79 & 0,79 \\
\hline Sal comum & 0,40 & 0,40 & 0,40 & 0,40 \\
\hline DL-metionina 99\% & 0,21 & 0,21 & 0,23 & 0,23 \\
\hline L-lisina HCL 99\% & 0,24 & 0,24 & 0,23 & 0,23 \\
\hline Caulim & 2,94 & 2,89 & 0,33 & 0,28 \\
\hline Complexo enzimático ${ }^{2}$ & -- & 0,05 & -- & 0,05 \\
\hline Suplemento mineral $^{3}$ & 0,05 & 0,05 & 0,05 & 0,05 \\
\hline Suplemento vitamínico ${ }^{4}$ & 0,05 & 0,05 & 0,05 & 0,05 \\
\hline Salinomicina & 0,02 & 0,02 & 0,02 & 0,02 \\
\hline Total & 100,00 & 100,00 & 100,00 & 100,00 \\
\hline \multicolumn{5}{|l|}{ Composição } \\
\hline Energia metabolizável (kcal/kg) & \multicolumn{2}{|c|}{2.946} & \multicolumn{2}{|c|}{3.100} \\
\hline Proteína bruta $(\%)^{5}$ & \multicolumn{2}{|c|}{17,76} & \multicolumn{2}{|c|}{18,73} \\
\hline Proteína bruta $(\%)^{6}$ & \multicolumn{2}{|c|}{17,10} & \multicolumn{2}{|c|}{18,00} \\
\hline Cálcio (\%) & \multicolumn{2}{|c|}{0,80} & \multicolumn{2}{|c|}{0,80} \\
\hline Fósforo disponível (\%) & \multicolumn{2}{|c|}{0,40} & \multicolumn{2}{|c|}{0,40} \\
\hline
\end{tabular}

${ }^{1}$ De acordo com as recomendações de Rostagno et al. (2005).

${ }^{2}$ De acordo com as recomendações do fabricante: $0,5 \mathrm{~kg} / \mathrm{t}$.

${ }^{3}$ Enriquecimento por kg de ração: 3,0 mg Cu; 0,4 mg I; 20,0 mg Fe; 40,0 mg Zn; 0,4 mg Mn; 0,1 mg Se.

${ }^{4}$ Enriquecimento por kg de ração: $10.000,0$ UI vit. A; 2.000,0 UI vit. D3; $10,0 \mathrm{mg}$ vit. E; $1,4 \mathrm{mg}$ vit. K; 6,0 mg riboflavina; $10,0 \mathrm{mg}$ pantotenato de cálcio; 300,0 mg niacina; 200,0 mg colina; $125.0 \mathrm{mg}$ BHT (antioxidante).

${ }^{5}$ Calculados de acordo com as recomendações de Rostagno et al. (2005).

${ }^{6}$ Determinada no Laboratório de Pesquisa Animal do DZO-UFLA. 
até o final da coleta quando foram pesadas, descongeladas, homogeneizadas e delas retiradas alíquotas de $300 \mathrm{~g}$ para as análises laboratoriais, passando por uma pré-secagem em estufa de ventilação forçada a $65^{\circ} \mathrm{C}$ até peso constante ou 72 horas. Após a pré-secagem, as amostras foram moídas em moinho tipo faca com peneira de 2 milímetros.

As análises foram realizadas no Laboratório de Pesquisa Animal do DZO/UFLA, determinando-se a matéria seca (MS), a energia bruta (EB) e o nitrogênio (N) das excretas e das rações experimentais. Com base nos resultados da energia bruta das rações e das excretas, determinada em bomba calorimétrica marca Parr, modelo 1261, foram calculados os valores da energia metabolizável aparente corrigida para o balanço de nitrogênio (EMAn), utilizando a equação descrita por Matterson et al. (1965).

Nos dois experimentos, as análises estatísticas foram realizadas utilizando-se software SAS ${ }^{\circledR}$ (SAS Institute, 1995) e as médias dos tratamentos, comparadas pelo teste de $\mathrm{F}$ a $5 \%$ de probabilidade.

\section{RESULTADOS E DISCUSSÃO}

\section{Ensaio de desempenho}

Pelos resultados de desempenho (Tabela 2) dos frangos de corte, no período de 22 a 42 dias de idade, observou-se diferenças estatísticas significativas $(\mathrm{p}<0,05)$ da forma física da ração no CR e no GP das aves no período estudado. Para a CA, foram observadas diferenças significativas para a forma física da ração e para o nível nutricional, bem como interação entre forma física da ração e nível nutricional $(\mathrm{p}<0,05)$.
$\mathrm{O}$ CR das aves que receberam as rações trituradas foi $2,91 \%$ menor, comparadas àquelas que consumiram as rações fareladas. Esses resultados são contrários aos obtidos por Greenwood et al. (2004) e Silveira et al. (2010), que avaliaram o desempenho produtivo de frangos de corte e não detectaram diferenças no CR das aves quando compararam rações peletizadas e fareladas. Todavia, López et al. (2007) e Lara et al. (2008) observaram maior CR de frangos de corte que receberam dietas processadas (peletizadas e peletizadas expandidas) em relação às rações fareladas, no período de um a 42 dias e de um a 45 dias de idade, respectivamente. Leczniezki et al. (2001), comparando o desempenho de frangos de corte de 21 a 42 dias de idade, utilizando rações peletizadas e fareladas, verificaram que o $\mathrm{CR}$ das aves que receberam rações peletizadas foi $2 \%$ superior ao daquelas alimentadas com rações fareladas.

As aves do presente trabalho, que consumiram as rações fareladas, apresentaram resultados de GP e CA 4,88 e $2,05 \%$ melhores, respectivamente, do que aquelas que consumiram as rações trituradas $(p<0,05)$, possivelmente devido ao maior consumo das rações fareladas que promoveram maior GP das aves na fase final de criação. Esses resultados são contraditórios aos obtidos por Brum et al. (2000) e Vargas et al. (2001), que obtiveram maior GP de frangos de corte de 22 a 35 dias de idade usando rações trituradas, em comparação às rações fareladas. Leczniezki et al. (2001), alimentando frangos de corte de 21 a 42 dias de idade com dietas peletizadas e fareladas, também verificaram maior peso corporal das aves que se alimentaram de dietas peletizadas em comparação ao peso das aves que receberam as dietas

Tabela 2 - Consumo de ração (CR), ganho de peso (GP) e conversão alimentar (CA) de frangos de corte de 22 a 42 dias de idade.

\begin{tabular}{|c|c|c|c|c|}
\hline \multirow{2}{*}{\multicolumn{2}{|c|}{ Tratamentos }} & \multicolumn{3}{|c|}{ Variáveis } \\
\hline & & Consumo de ração $(\mathrm{g})$ & Ganho de peso $(\mathrm{g})$ & Conversão alimentar $(\mathrm{g} / \mathrm{g})$ \\
\hline \multirow{2}{*}{ Forma Física } & Farelada & 3294 a & $1720 \mathrm{a}$ & $1,91 \mathrm{a}$ \\
\hline & Triturada & $3198 \mathrm{~b}$ & $1640 \mathrm{~b}$ & $1,95 \mathrm{~b}$ \\
\hline \multirow{2}{*}{$\begin{array}{l}\text { Complexo } \\
\text { Enzimático }\end{array}$} & Sem & $3258 \mathrm{a}$ & 1689 a & $1,93 \mathrm{a}$ \\
\hline & Com & $3234 \mathrm{a}$ & $1670 \mathrm{a}$ & $1,93 \mathrm{a}$ \\
\hline \multirow{2}{*}{ Nível Nutricional } & $95 \%$ & $3277 \mathrm{a}$ & $1661 \mathrm{a}$ & $1,97 \mathrm{~b}$ \\
\hline & $100 \%$ & $3215 \mathrm{a}$ & $1699 \mathrm{a}$ & $1,89 \mathrm{a}$ \\
\hline \multicolumn{2}{|c|}{ Média } & 3246 & 1680 & 1,93 \\
\hline \multicolumn{2}{|c|}{ Coeficiente de variação (\%) } & 3,38 & 4,27 & 2,05 \\
\hline
\end{tabular}

Letras a,b - na coluna, entre forma física, complexo enzimático ou nível nutricional $(\mathrm{p}<0,05)$. 
fareladas. Os resultados estão de acordo com Vargas et al. (2001), que verificaram melhor CA $(\mathrm{p}<0,05)$ de frangos que receberam ração triturada dos 21 aos 35 dias de idade. Todavia, Lara et al. (2008), alimentando frangos de corte com ração farelada e peletizada a vontade, de um a 45 dias de idade, não observaram diferenças em relação a CA no período de um a 45 dias de idade $(\mathrm{p}<0,05)$.

$\mathrm{Na}$ CA das aves, o nível nutricional com $100 \%$ das recomendações nutricionais promoveu melhores respostas $(\mathrm{p}<0,05)$. No entanto, a interação observada $(\mathrm{p}<0,05)$ entre nível nutricional e forma física da ração (Tabela 3) mostrou que não houve diferença significativa dos resultados de CA, na forma física da ração $(p>0,05)$, quando se utilizou o nível de $95 \%$ das recomendações. Todavia, verificou-se uma melhora na CA das aves que utilizaram as rações fareladas com $100 \%$ das exigências em comparação àquelas que receberam rações trituradas com o mesmo nível nutricional $(\mathrm{p}<0,05)$. Neste caso, pode-se inferir que o efeito dos $100 \%$ das recomendações nutricionais só foi totalmente expresso com as rações na forma farelada, ou seja, naquelas dietas que não passaram pelo processo de peletização e posterior trituração.

Os resultados obtidos (Tabela 2) mostraram que o complexo enzimático não influenciou o desempenho das aves no período avaliado, corroborando os resultados de Torres et al. (2003), Rodrigues et al. (2003), Pucci et al. (2003), Strada et al. (2005), que também não verificaram influência da utilização de complexos enzimáticos compostos por carboidrases e proteases em rações à base de milho e farelo de soja no desempenho de frangos de corte. Entretanto, Zanella et al. (1999), Fischer et al. (2002), Souza et al. (2008) e Carvalho et al. (2009), utilizando dietas a base de milho e farelo de soja, mostraram efeitos positivos da suplementação com complexos enzimáticos para as variáveis de desempenho ( $\mathrm{CR}, \mathrm{GP}$ e CA), demonstrando que as enzimas também melhoram o aproveitamento dos alimentos em aves mais velhas e não apenas quando essas ainda possuem o aparelho digestório pouco desenvolvido, como na fase inicial.

Dessa forma, de acordo com os resultados obtidos neste trabalho, tanto com as rações fareladas quanto com as trituradas, não há evidência clara de efeito da suplementação enzimática sobre o desempenho das aves. Assim, não foi possível avaliar o efeito da peletização sobre a termoestabilidade das enzimas componentes do complexo enzimático. No presente trabalho, destaca-se que a temperatura de peletização no condicionador e na saída da matriz oscilou de 64 a $79^{\circ} \mathrm{C}$ e de 71 a $83,5 \%$, respectivamente, possivelmente não sendo excessiva para prejudicar a estabilidade das enzimas.

As dietas não influenciaram $(p>0,05)$ as características de carcaça estudadas como: rendimento de carcaça, rendimento de peito, rendimento de coxa + sobre coxa e o teor de gordura abdominal (Tabela 4).

Os resultados de características de carcaça encontradas neste trabalho são contrários, em parte, aos obtidos por Souza et al. (2008), que trabalharam com dietas fareladas e peletizadas para frangos de corte e observaram melhor rendimento de carcaça nos frangos que receberam rações peletizadas. Todavia, para o rendimento de peito e coxa + sobrecoxa, os referidos autores não verificaram influência devido à forma física da ração $(p>0,05)$. Entretanto, corroboram com os resultados obtidos por Zanotto et al. (2006) e Souza et al. (2008), que não encontraram efeito da forma física da ração, comparando ração farelada e peletizada sobre rendimento de cortes de frangos de 1 a 42 dias de idade.

Carvalho et al. (2009), trabalhando com dietas suplementadas com complexo enzimático, não verificaram efeito das enzimas para os rendimentos de carcaça e peito e na porcentagem de gordura abdominal das aves até os 42 dias de idade. Resultados semelhantes foram encontrados por Zanella et al. (1999) e Torres et al. (2003), que não encontraram influência da utilização de enzimas no rendimento de carcaça. Entretanto, resultados positivos de gordura abdominal foram encontrados por Torres et al.

Tabela 3 - Conversão alimentar (CA) em função do nível nutricional e forma física da ração de frangos de corte de 22 a 42 dias de idade.

\begin{tabular}{cccc}
\hline \multicolumn{2}{c}{ Conversão alimentar $(\mathrm{g} / \mathrm{g})$} & & \multicolumn{2}{c}{ Forma Física } \\
\cline { 3 - 4 } Nível Nutricional & $95 \%$ & $1,97 \mathrm{Ba}$ & Triturada \\
\hline Média & $100 \%$ & $1,86 \mathrm{Aa}$ & $1,97 \mathrm{Ba}$ \\
\hline Coeficiente de Variação $(\%)$ & & 1,91 & $1,92 \mathrm{Ab}$ \\
\hline
\end{tabular}

Letras maiúsculas na coluna (A,B) e letras minúsculas na linha $(a, b)$ diferem pelo teste $\mathrm{F}(\mathrm{p}<0,05)$. 
(2003) e Souza et al. (2008), que verificaram que a utilização de enzimas promoveu aumento no teor de gordura abdominal na carcaça das aves, o que pode ser explicado por um possível aumento na liberação de energia dos nutrientes, através da suplementação enzimática. $\mathrm{O}$ excesso de energia ingerida além das necessidades teria sido acumulado na forma de gordura na carcaça, fato que não foi observado no presente estudo. Assim, pelos resultados obtidos, pode-se concluir que os tratamentos estudados não interferiram de maneira expressiva nas características de carcaça dos frangos.

\section{Ensaio de metabolismo}

Os resultados do ensaio de metabolismo (experimento 2), referentes à energia metabolizável aparente corrigida (EMAn) e aos coeficientes de metabolizabilidade da matéria seca e da proteína bruta (Tabela 5), demonstram

Tabela 4 - Rendimento de carcaça (RC), rendimento de peito (RP), rendimento de coxa e sobre coxa (RC+SC) e gordura abdominal (GA) de frangos de corte de 22 a 42 dias de idade.

\begin{tabular}{|c|c|c|c|c|c|}
\hline \multicolumn{2}{|c|}{ Tratamentos } & \multicolumn{4}{|c|}{ Variáveis } \\
\hline rratam & & \multirow{2}{*}{$\begin{array}{c}\mathrm{RC}(\%) \\
72,00\end{array}$} & \multirow{2}{*}{$\frac{\mathrm{RP}(\%)}{34,14}$} & \multirow{2}{*}{$\frac{\mathrm{RC}+\mathrm{SC}(\%)}{30,39}$} & \multirow{2}{*}{$\begin{array}{c}\text { GA }(\%) \\
1,55\end{array}$} \\
\hline Eormo Eúciso & Farelada & & & & \\
\hline Forma Fisica & Triturada & 71,70 & 35,32 & 31,12 & 1,46 \\
\hline \multirow{2}{*}{ Complexo Enzimático } & Sem & 71,70 & 34,90 & 30,66 & 1,54 \\
\hline & Com & 72,00 & 34,56 & 30,85 & 1,47 \\
\hline \multirow{2}{*}{ Nível Nutricional } & $95 \%$ & 71,65 & 34,66 & 30,73 & 1,55 \\
\hline & $100 \%$ & 72,05 & 34,80 & 30,77 & 1,45 \\
\hline \multicolumn{2}{|c|}{ Média } & 71,85 & 34,73 & 30,75 & 1,50 \\
\hline \multicolumn{2}{|c|}{ Coeficiente de variação (\%) } & 1,93 & 4,04 & 3,15 & 19,77 \\
\hline
\end{tabular}

$(\mathrm{p}>0,05)$

Tabela 5 - Energia metabolizável aparente corrigida (EMAn) e coeficientes de metabolizabilidade da matéria seca (CMMS) e da proteína bruta (CMPB) das rações experimentais oferecidas aos frangos de corte de 22 a 42 dias de idade.

\begin{tabular}{|c|c|c|c|c|}
\hline \multicolumn{2}{|c|}{ Tratamentos } & \multicolumn{3}{|c|}{ Variáveis } \\
\hline Tratal & & $\begin{array}{c}\text { EMAn } \\
(\mathrm{kcal} / \mathrm{kg} \mathrm{MS})\end{array}$ & CMMS (\%) & СMPB $(\%)$ \\
\hline \multirow{2}{*}{ Forma Física } & Farelada & $3318 \mathrm{~b}$ & $77,00 \mathrm{a}$ & $63,55 \mathrm{a}$ \\
\hline & Triturada & $3373 \mathrm{a}$ & $77,00 \mathrm{a}$ & $64,27 \mathrm{a}$ \\
\hline \multirow{2}{*}{ Complexo Enzimático } & Sem & $3364 \mathrm{a}$ & $77,17 \mathrm{a}$ & $63,93 \mathrm{a}$ \\
\hline & Com & $3327 \mathrm{~b}$ & $76,80 \mathrm{a}$ & $63,88 \mathrm{a}$ \\
\hline \multirow{2}{*}{ Nível Nutricional } & $95 \%$ & $3262 \mathrm{~b}$ & $76,20 \mathrm{~b}$ & $63,06 \mathrm{~b}$ \\
\hline & $100 \%$ & 3429 a & $77,77 \mathrm{a}$ & $64,76 \mathrm{a}$ \\
\hline \multicolumn{2}{|c|}{ Média } & 3346 & 77,00 & 63,91 \\
\hline \multicolumn{2}{|c|}{ Coeficiente de variação (\%) } & 1,34 & 1,48 & 3,42 \\
\hline
\end{tabular}

Letras maiúsculas na coluna (A,B) e letras minúsculas na linha $(a, b)$ diferem pelo teste $\mathrm{F}(\mathrm{p}<0,05)$. 
efeito $(\mathrm{p}<0,05)$ da forma física da ração, do complexo enzimático e do nível nutricional sobre EMAn, bem como efeito do nível nutricional sobre os CMMS e CMPB.

Comparando as rações fareladas às trituradas, observou-se efeito $(p<0,01)$ da forma física somente para o valor energético das rações, sendo que as rações trituradas apresentaram valor de EMAn 1,66\% superior às rações fareladas. A melhora no valor energético destas rações possivelmente foi suficiente para refletir no menor $\mathrm{CR}$, porém sem efeito para GP e CA das aves que receberam as rações trituradas. López et al. (2007) também verificaram influência positiva dos processamentos (peletização e peletização + expansão) sobre os valores de EMAn para frangos de corte. Os referidos autores concluíram que o efeito benéfico seria devido às mudanças induzidas pelo processamento e pelo melhoramento da eficiência da digestão e absorção, possivelmente em função do efeito conjunto de temperatura e pressão que podem ter quebrado a estrutura da parede celular e/ou induzido algumas mudanças na química dos nutrientes da dieta, fazendo-os mais digeríveis pelas enzimas do trato gastrintestinal.

Para as aves que receberam a ração com suplementação enzimática, observaram-se valores de EMAn $1,10 \%$ inferiores $(p<0,05)$ às rações que não continham o complexo enzimático. Pucci et al. (2003), trabalhando com complexo enzimático contendo xilanase, amilase e protease com frangos de corte no mesmo período de criação, não encontraram efeito significativo ( $>0,05)$ para os valores de EMAn das rações com e sem suplementação enzimática. Esses resultados discordam dos obtidos por Caires et al. (2008) e Carvalho et al. (2009) que encontraram melhores valores de EMAn em dietas suplementadas com complexo enzimático. Dourado et al. (2009), suplementando rações com complexo enzimático e redução de energia e proteína, demonstraram que as enzimas são eficientes em restabelecer os valores de EMAn das rações à base de milho e farelo de soja. Os resultados positivos com a utilização de enzimas para os valores de EMAn são esperados devido ao fato de uma enzima digestiva liberar mais nutrientes e, consequentemente energia, fato não observado no presente estudo.

Não foram observadas diferenças $(p>0,05)$ nos CMMS e CMPB quando as rações foram suplementadas com o complexo enzimático. No entanto, Zanella et al. (1999), diferentemente dos resultados encontrados, relataram melhoria no CMPB com uso de um complexo enzimático contendo xilanase, amilase e protease.
Entretanto, Carvalho et al. (2009), suplementando rações para frangos de corte no mesmo período de criação, com as mesmas enzimas (xilanase, amilase e protease), também não observaram efeito das enzimas na digestibilidade da proteína e da matéria seca.

As aves que receberam as rações com o nível nutricional em $100 \%$ das exigências recomendadas tiveram, como esperado, valores de EMAn, CMMS e CMPB superiores, em comparação as rações com $95 \%$ das recomendações nutricionais $(\mathrm{p}<0,05)$.

Para o CMPB, observou-se interação $(\mathrm{p}<0,01) \mathrm{da}$ forma física e nível nutricional (Tabela 6). A ração farelada, em 100\% das exigências nutricionais, promoveu um CMPB significativamente superior em relação à ração com $95 \%$ das exigências, enquanto que para a ração triturada, entre os dois níveis nutricionais, não foram observadas diferenças $(\mathrm{p}>0,05)$.

Tabela 6 - Coeficiente de metabolizabilidade da proteína bruta (CMPB) em função do nível nutricional e da forma física da ração de frangos de corte de 22 a 42 dias de idade.

\begin{tabular}{cccc}
\hline \multirow{2}{*}{ CMPB (\%) } & & \multicolumn{2}{c}{ Forma Física } \\
\cline { 2 - 4 } & & Farelada & Triturada \\
\hline \multirow{2}{*}{ Nível Nutricional } & $95 \%$ & $62,00 \mathrm{Bb}$ & $64,11 \mathrm{Aa}$ \\
& $100 \%$ & $65,10 \mathrm{Aa}$ & $64,42 \mathrm{Aa}$ \\
\hline Média & \multicolumn{2}{c}{63,55} & 64,26 \\
\hline Coeficiente de & \multicolumn{2}{c}{3,42} \\
Variação (\%) & \multicolumn{2}{c}{} \\
\hline
\end{tabular}

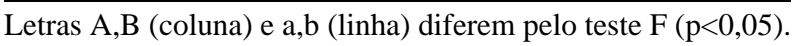

Com relação à forma física da ração, o CMPB das aves que receberam as rações trituradas com $95 \%$ das exigências nutricionais foi maior $(\mathrm{p}<0,05)$ em comparação àqueles das rações fareladas, com o mesmo nível nutricional. No entanto, esta diferença não se repetiu em se tratando de rações com 100\% das recomendações.

\section{CONCLUSÕES}

O processamento das rações influencia o desempenho das aves e as rações trituradas promove maiores valores de EMAn. As características de carcaça não foram influenciadas pelos tratamentos experimentais avaliados. Nas condições avaliadas, o complexo enzimático não melhorou o desempenho das aves nem a digestibilidade dos nutrientes. O nível nutricional em 100\% das recomendações nutricionais, independentemente da 
forma física da ração, promove melhor GP e CA, como também os maiores valores de EMAn, CMMS e CMPB.

\section{REFERÊNCIAS BIBLIOGRÁFICAS}

BRUM, P. A. R.; MAZZUCO, H.; FIALHO, F. B.; GUARIENTI, E. M.; VIOLA, E. S. Efeito do nível de trigo na dieta, do percentual de grãos germinados e da forma física da ração sobre o desempenho de frangos de corte. Revista Brasileira de Zootecnia, Viçosa, MG, v. 29, n. 1, p. 168-176, 2000.

CAIRES, C. M.; FAGUNDES, N. S.; FERNANDES, E. A.; CARVALHO, A. P. de. Revista Eletrônica Nutritime, v.5, $\mathrm{n}^{\circ}$ 1, p.491-497, Janeiro/Fevereiro 2008. Disponível em: $\langle$ http://www.nutritime.com.br/arquivos internos/artigos/ '049V5N1P491_497_JAN2008.pdf'! Acesso em: 17 nov. 2010.

CARVALHO, J.C.C.; BERTECHINI, A.G; FASSANI, E.J. Desempenho e características de carcaça de frangos de corte alimentados com dietas à base de milho e farelo de soja suplementadas com complexos enzimáticos. Revista Brasileira de Zootecnia, Viçosa, v.38, n.2, p.292-298, 2009.

DOURADO, L. R. B.; SAKOMURA, N. K.; BARBOSA, N. A. A; BONATO, M. A.; KAWAUCHI, I. M.; FERNANDES, J. K; COSTA, F. G. P. Corn and Soybean Meal Metabolizable Energy with the Addition of Exogenous Enzymes for poultry. Revista Brasileira de Ciência Avícola, v. 11, p. 51-55, 2009.

FISCHER, G.; MAIER, J.C.; RUTZ, F. Desempenho de frangos de corte alimentados com dietas a base de milho e farelo de soja, com ou sem adição de enzimas. Revista Brasileira de Zootecnia, Viçosa, v.31, n.1, p.402-410, 2002.

LARA, L.J.C.; BAIÃO, N.C.; ROCHA, J.S.R. Influência da forma física da ração e da linhagem sobre o desempenho e rendimento de cortes de frangos de corte. Arquivo Brasileiro de Medicina Veterinária e Zootecnia, Belo Horizonte, v.60, n.4, p.970-978, 2008.

LOGATO, P.V.R.; ALBERNAZ, N. da S.; RIBEIRO, P.A.P.; FREITAS, R.T.F de, FIALHO, E.T. Effect of the ration processing on the apparent digestibility values of nutrients for the Piau (Leporinus elongatus). Revista
Ciência e Agrotecnologia, Lavras, v.33, n.3, p.890-894, maio/jun., 2009.

MATTERSON, L.D.; POTTER, L.M.; STUTZ, M.W. The metabolizable energy of feed ingredients for chickens. Connecticut: The University of Connecticut. Agricultural Experiment Station, 1965. (Research Report, 7).

PUCCI, L.E.A.; RODRIGUES, P.B.; FREITAS, R.T.F. Níveis de óleo e adição de complexo enzimático na ração de frangos de corte. Revista Brasileira de Zootecnia, Viçosa, v.32, n.4, p.909-917, 2003.

RODRIGUES, P.B.; MARTINEZ, R. de S.; FREITAS, R.T.F. Influência do tempo de coleta e metodologias sobre a digestibilidade e o valor energético de rações para aves. Revista Brasileira de Zootecnia, Viçosa, v.34, n.3, p.882-889, 2005.

RODRIGUES, P.B.; ROSTAGNO, H.S.; ALBINO, L.F.T. Desempenho de frangos de corte, digestibilidade de nutrientes e valores energéticos de rações formuladas com vários milhos, suplementadas com enzimas. Revista Brasileira de Zootecnia, Viçosa, v.32, n.1, p.171-182, 2003.

ROSTAGNO, H.S.; ALBINO, L.F.T.; DONZELE, J.L. Tabelas brasileiras para suínos e aves: composição de alimentos e exigências nutricionais. 2.ed. Viçosa, MG: UFV/DZO, 2005. 186p.

SAS INSTITUTE. SAS/STAT ${ }^{\circledR}$ : user's guide: version 6. 2.ed. Cary, 1995.

SILVEIRA, M.H.D. da; USSO, J.T.Z.; ROSSI, P. Efeito da peletização em dietas contendo complexo enzimático para frangos de corte. Ciência Animal Brasileira, Goiânia, v.11, n.2, p.326-333, abr./jun. 2010.

SOUZA, R.M. de; BERTECHINI, A.G.; SOUZA, R.V. et al. Efeito da suplementação enzimática e da forma física da ração sobre o desempenho e as características de carcaça de frangos de corte. Revista Ciência e Agrotecnologia, Lavras, v.32, n.2, p.584-590, mar./abr. 2008.

STRADA, E.S.O.; ABREU, R.D.; OLIVEIRA, G.J. Uso de enzimas na alimentação de frangos de corte. Revista Brasileira de Zootecnia, Viçosa, v.34, n.6, p.2369-2375, 2005. 
TORRES, D.M.; TEIXEIRA, A.S.; RODRIGUES, P.B. Eficiência das enzimas amilase, protease e xilanase sobre o desempenho de frangos de corte. Revista Ciência e Agrotecnologia, Lavras, v.27, p.1401-1408, 2003.

VARGAS, G.D.; BRUM, P.A.R.; FIALHO, F.B. Efeito da forma física da ração sobre o desempenho de frangos de corte machos. Revista Brasileira de Agrociência, Pelotas, v.7, n.1, p.42-45, jan./abr. 2001.

ZANELLA, I.; SAKOMURA, N.K.; FIGUEIREDO, A.; SILVERSIDES, F.G. Effect of enzyme supplementation of broiler diets based on corn and soybeans. Poultry Science, Champaign, v.78, n.4, p.561-568, Apr. 1999.

ZANOTTO, D. L; BELLAVER, C. Método de determinação de granulometria de ingredientes para uso em rações de suínos e aves. Concórdia: Embrapa, 1996. 5p. (Comunicado técnico, 215).

ZANOTTO, D. L.; SCHMIDT, G. S.; GUIDONI, A. L.; BRUM, P. A. R. de; ROSA, P. S. Tamanho das partículas do milho e forma física da ração: desempenho e rendimento de carcaça em frangos de corte. Concórdia, SC: Embrapa Suínos e Aves, 2006 (Comunicado Técnico, 435). Disponível em: Swww.cnpsa.embrapa.br/sgc/sgc_publicacoes/ publicacao_16z9c1sipdf $>$. Acesso em: 17 nov. 2010. 